\title{
Population dynamics of Fiorinia phoenicis (Hemiptera-Diaspididae) on date palm at Baharia Oases, Giza governorate, Egypt
}

\author{
I.R.M. El-Zoghby \\ Plant Prot. Dept., Faculty of Agric. and Natural Resources, \\ Aswan Univ., Aswan, Egypt
}

\begin{abstract}
The population dynamics of Fiorinia date scale, Fiorinia phoenicis (Hemiptera - Diaspididae) was studied for two successive years (2012/2013 and 2013/2014) on date palm cultivated at Baharia Oases, Giza Governorate. The obtained results revealed that, Fiorinia phoenicis has three annual field generations on date palm peaked in June/July; September and November in the two years. The longest generation occurred in autumn with duration of 5 months at mean temp. and R.H $\left(21.4^{\circ} \mathrm{C} \& 65.5 \%\right.$ R.H. and $22.8^{\circ} \mathrm{C} \& 66.2 \%$ R.H. $)$, for the $1^{\text {st }}$ and $2^{\text {nd }}$ year respectively, whereas the shortest one was found in late summer with duration of 3 months at mean temp. and R.H $\left(26.3^{\circ} \mathrm{C} \& 66.0 \%\right.$ R.H. and $27.8^{\circ} \mathrm{C} \& 64.8 \%$ R.H. $)$, for the $1^{\text {st }}$ and $2^{\text {nd }}$ year respectively. The intermediate generation occurred in early summer with duration of 4 months at mean temp. and R.H $\left(22.8^{\circ} \mathrm{C} \&\right.$ $63.4 \%$ R.H. and $24.9^{\circ} \mathrm{C} \& 63.6 \%$ R.H.) for the $1^{\text {st }}$ and $2^{\text {nd }}$ year, respectively.

The generation size varied in the two years, the autumn generation is the largest one (12259.8 \& 12153.4 insects), for the $1^{\text {st }}$ and $2^{\text {nd }}$ year respectively, followed by late summer generation (8184.2 \& 7430.4 insects), for the $1^{\text {st }}$ and $2^{\text {nd }}$ year respectively), while early summer generation was the lowest one $(6688.3 \& 7422.1$ insects), for the $1^{\text {st }}$ and $2^{\text {nd }}$ year, respectively.

The population of $F$. phoenicis was found to be distributed at random on the date palm fronds especially the older ones. The cardinal directions of the date palm received similar portions of insect population except for the south direction which received the highest portion of insect population $(26.8 \& 28 \%)$, for the $1^{\text {st }}$ and $2^{\text {nd }}$ year respectively, and become relatively warmer and preferred for infestation than the other side's which received lesser and apparently similar portions of insect population $(25.1,23.9 \%$ \& $23.8,24.3 \%$ and $24.3,23.8 \%$ ), for East, West and North directions ( the $1^{\text {st }}$ and $2^{\text {nd }}$ year ),respectively.

The distribution of $F$. phoenicis population on the different parts of the date palm leaflets varied, as the middle stratum received the highest portion of insect population $(40.0 \& 43.4 \%)$ followed by basal stratum $(34.3 \& 33.3 \%)$ and apical stratum $(25.7 \& 23.3 \%)$ for the $1^{\text {st }}$ and $2^{\text {nd }}$ year, respectively.

On the other hand, the insect activity was significantly affected by the daily mean minimum and maximum temperatures as well as \% R.H. The changes in the half monthly counts of population, which were affected by the combined effect of these factors, which ranged (61.6 \& $72.5 \%$ and $59.4 \& 66.7 \%$ ), for nymphs and adults (the $1^{\text {st }}$ and $2^{\text {nd }}$ year, respectively).

So, the annual pruning of date palm and offshoots by removing the infested old fronds (lower fronds) is necessary for reducing the insect population and to save the date palm and dates from infestation by $F$. phoenicis as well as to reduce the chemical control in order to keep the environment free from any contamination with pesticides.
\end{abstract}

Keywords: Population dynamics, Fiorinia phoenicis, date palm.

\section{Introduction}

Fiorinia date scale, Fiorinia phoenicis Balachowsky, 1967 (Hemiptera: Diaspididae) is an economic important scale insect on date palm (Phoenix dactylifera L.). The scale was recorded by Ghabbour and Mohammad (2010) as new pest on date palm in Egypt.

Fiorinia date scale mainly attacks the fronds of the date palm and occasionally the dates; field observation showed that the pinnae of old date palm fronds (lower fronds) were heavily infested with $F$. phoenicis than the new ones. In case of severe infestation the crawlers move to the date bunches and infest the dates during the fruiting season forming thick crusts, making the dates unsuitable for human consumption. The severe infestation greatly affected the growth of date palm specially the offshoots causing yellowish of the pinnae and dryness of the fronds.

In Egypt, some studies were carried out on the bionomics of $F$. phoenicis on date palm at Giza and Qalubyia Governorates (Elwan et al., 2011 and Radwan, 2012) but necessarily further studies are needed on the insect bionomics and its associated natural enemies in other governorates to evaluate the role of natural enemies as biological agents for its control.

Fiorinia phoenicis was recorded in many countries such as Iraq (Hussain, 1974); Saudi Arabia (Matile, 1984); Oman (Elwan, 2000); Iran (Takagi \&Moghaddam, 2005); Egypt (Mohammed \& Ghabbour, 2008 ; Ghabbour \& Mohammad, 2010) and Spain (Seljak \& Matile,2012). 
The present work was conducted on $F$. phoenicis at Baharia Oases, Giza Governorate to study the bionomics of the scale, its seasonal activity, number and duration of annual field generations, distribution of insect populations on the cardinal directions of date palm fronds as well as on the leaflet stratum besides the effect of main weather factors on its activity under environmental conditions of Baharia Oases, Giza Governorate.

\section{Material and methods}

The present work was carried out for two successive years (2012/2013 and 2013/2014) on date palm (Sewy cultivar) cultivated in Baharia Oases, Giza Governorate. The selected date palm received the normal agricultural practices without pruning nor application of any chemical control measure before and during the period of study. Four date palm trees of almost similar age, vegetation and height were randomly selected and sampling was practiced at half monthly intervals. A random sample of 20 leaflets was taken from the cardinal directions of each date palm with rate of 5 leaflets/direction (North, South, East and West), respectively. The collected samples were preserved in paper bags and transferred to the laboratory for inspection with abinocular stereoscopic-microscope. In the laboratory, each leaflet was divided into three equal strata (basal, middle and apical) then the insect population was counted and sorted to nymph and adults in each stratum. The half-monthly means of nymphs and adults population per leaflet were graphically illustrated and the number of annual field generations was determined by integrating of the population curves in these figures. Distributions of insect population on the date palm fronds in the four cardinal directions as well as on the three leaflet stratums were determined. The half monthly means of maximum and minimum temperatures as well as relative humidity were obtained from the Meteorological Central Laboratory, Agricultural Research Center, Dokki, Giza. The obtained weather factors were correlated with the insect population and the simultaneous effect (Fisher, 1950) of the these factors on the variability within the insect population was done by using computer (MSTATC Program) to determine their effect on the insect activity in the two studied years.

\section{Results and Discussion}

The seasonal activity of $F$. phoenicis was determined for two seasons (2012/2013 and 2013/2014) on date palm cultivated at Baharia Oases, Giza Governorate. The obtained results showed the half-monthly variation in the seasonal activity of the nymph and adult female populations of F. phoenicis in both studied years (Figs., $1 \& 2$ ). The initial mean count of nymph and adult populations in $1^{\text {st }}$ March ranged 228.9-245.1 nymphs and 127.1132.6 adults/leaflet for the $1^{\text {st }}$ and $2^{\text {nd }}$ year respectively. These counts increased gradually in April and May. The insect population increased greatly during June and July in the two years recording the $1^{\text {st }}$ peak for insect activity in mid-June in the $1^{\text {st }}$ year and $1^{\text {st }}$ July in the $2^{\text {nd }}$ one $(695-765.3$ nymphs and 447-501.2 adults/leaflet), for the $1^{\text {st }}$ and $2^{\text {nd }}$ year respectively at field conditions $25.2-26.0^{\circ} \mathrm{C}$ and $63.8-63.9 \%$ R.H., respectively.

The insect population showed gradual decrease in July $2^{\text {nd }}$ in the two years followed by gradual increase by late August and high increases during September in the two years, respectively. In early and mid-September, the insect population reached the $2^{\text {nd }}$ peak in the $2^{\text {nd }}$ and $1^{\text {st }}$ year with mean population ranged 931.1-1026.9 nymphs/leaflet and 584.5-621.0 adults/leaflet at $27.7-28.6^{\circ} \mathrm{C}$ and $62.6-$ $66.4 \%$ R.H., respectively.

The population decreased in the $1^{\text {st }}$ half of October then increased again through the $2^{\text {nd }}$ half of October in the two years. The insect activity reached its maximum during November in the two years recording $3^{\text {rd }}$ peak by early November in the $1^{\text {st }}$ year and mid-November in the $2^{\text {nd }}$ one $(1300.6-1450.8$ nymphs/leaflet and 907.0-914.7 adults/leaflet)at 21.7 $-23.9^{\circ} \mathrm{C}$ and $62.6-66.4 \%$ R.H., respectively.

During December, the insect population showed gradual decrease of the nymph and adult populations in the two years. This decrease continued during January and February until reaching 176.0 190.4 nymphs/leaflet and 211.0-295.1 adults/leaflet by mid-February at $14.3-14.5^{\circ} \mathrm{C}$ and $62.0-63.3 \%$ R.H.

According to the above-mentioned results, $F$. phoenicis has three annual peaks per year under field conditions of Baharia Oases, Giza Governorate. The annual peaks occurred in June/July, September and November in the two years of study. So, the annual pruning of date palm and offshoots by removing the infested old fronds are necessary for reducing the insect population to the minimum in order to save the date palm and dates from infestation with $F$. phoenicis and to avoid application of chemical control and subsequently keep environment free from any contamination with pesticides.

In agreement with the present results, Elwan et al. (2011) recorded three annual peaks a year for $F$. phoenicis on date palm in Giza governorate, Egypt. Those appeared in early June, around August/September and October/November, whereas Radwan (2012) reported two periods of seasonal activity for $F$. phoenicis population (nymphal and adult stages) per year on date palm in Qalubyia Governorate.

The $1^{\text {st }}$ period of nymphal activity occurred in autumn, peaked in early December and the $2^{\text {nd }}$ period occurred in summer season peaked in early July. 

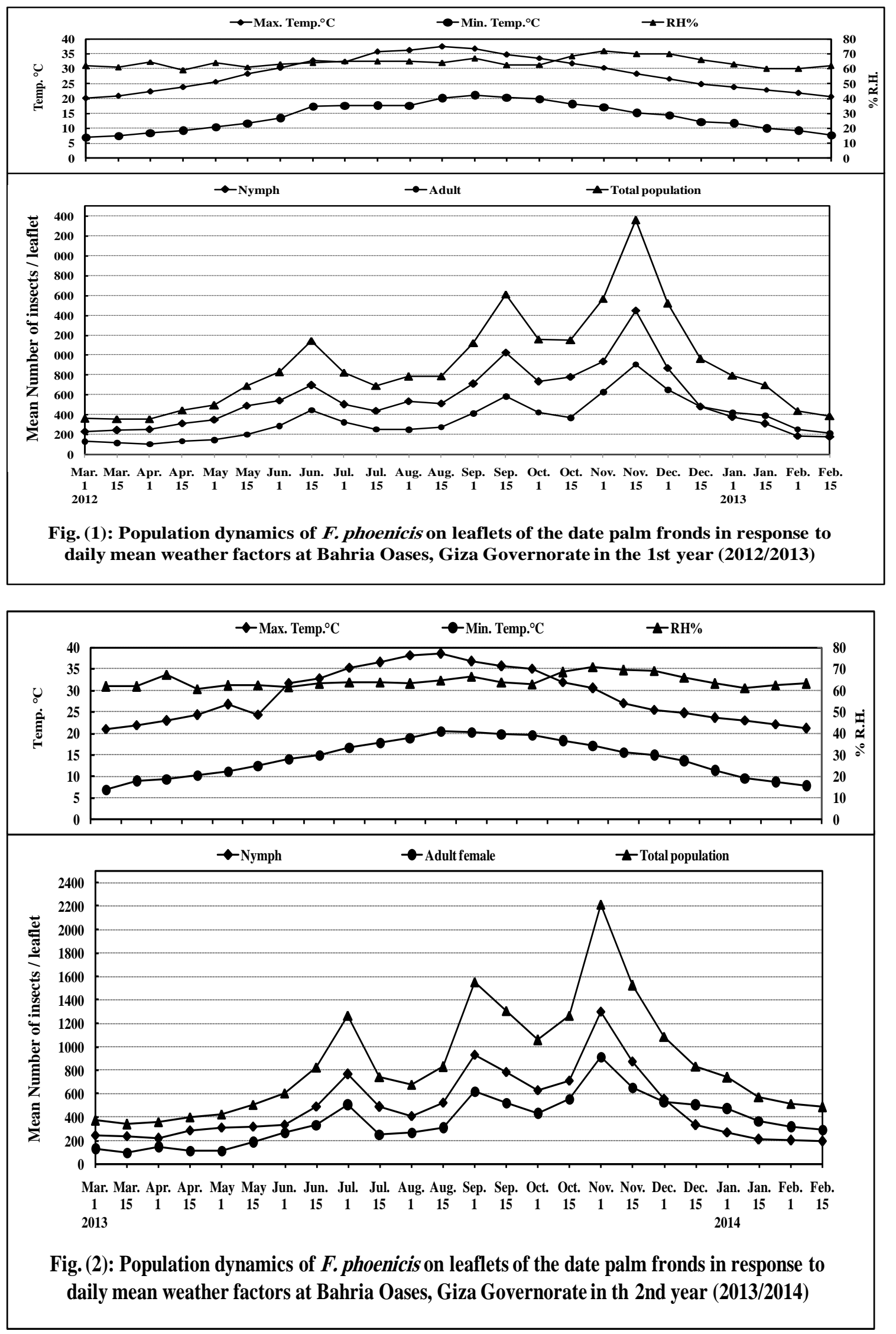
The $1^{\text {st }}$ period of adult activity appeared during autumn-winter seasons with one peak in early February and the $2^{\text {nd }}$ period appeared during summer season peaked in early July.

\section{Number and durations of annual field generations of $F$. phoenicis}

Number and duration of annual field generations of $F$. phoenicis were determined by integrating the population curves in each generation (Table1,2 \& Fig.,3).The obtained results may be discussed as follows:

\section{1- The $1^{\text {st }}$ generation (early summer)}

The $1^{\text {st }}$ generation started from mid-April to midAugust peaked in mid-June (695 nymphs / leaflet) in the $1^{\text {st }}$ year at $22.9^{\circ} \mathrm{C} \& 63.9 \%$ R.H. whereas in the $2^{\text {nd }}$ year, it appeared from early May to early September peaked in first July(765.3 nymphs/leaflet) at $26.0^{\circ} \mathrm{C} \& 63.8 \%$ R.H

\section{2- The $2^{\text {nd }}$ generation (Late summer)}

The $2^{\text {nd }}$ generation appeared from early August and extended to early November peaked in midSeptember (1026.9 nymphs/leaflet) in the $1^{\text {st }}$ year at $27.7^{\circ} \mathrm{C} \& 62.6 \%$ R.H., while in the $2^{\text {nd }}$ year, it occurred from mid-July to mid-October peaked in first September $\left(931.0\right.$ nymphs/leaflet) at $28.6^{\circ} \mathrm{C} \&$ $66.4 \%$ R.H.

\section{3- The $3^{\text {rd }}$ generation (Autumn)}

The $3^{\text {rd }}$ generation occurred between midSeptember and mid-February peaked in midNovember (1450.8 nymphs/leaflet) in the $1^{\text {st }}$ year at $21.7^{\circ} \mathrm{C} \& 70 \%$ R.H., whereas in the $2^{\text {nd }}$ year, it started from September $1^{\text {st }}$ and continued until late January, peaked in $1^{\text {st }}$ November $(1300$ nymphs/leaflet) at field conditions of $23.9^{\circ} \mathrm{C} \& 71.2$ $\%$ R.H.

The obtained results revealed that, the $1^{\text {st }}$ generation of $F$. phoenicis lasted for four months with population of $4370.0 \& 4567.7$ nymphs/leaflet and $2318.3 \& 2854.4$ adults/leaflet at $22.8^{\circ} \mathrm{C} \& 63.4$ $\%$ R.H. and $24.9^{\circ} \mathrm{C} \& 63.6 \%$ R.H., for the $1^{\text {st }}$ and $2^{\text {nd }}$ year, respectively. The $2^{\text {nd }}$ generation extended for three months with population of $4472.5 \& 5231.1$ nymphs/leaflet and $2953.1 \& 2957.9$ adults/leaflet at $26.3^{\circ} \mathrm{C} \& 66.0 \%$ R.H. and $27.8^{\circ} \mathrm{C} \& 64.8 \%$ R.H., for the $1^{\text {st }}$ and $2^{\text {nd }}$ year, respectively. The $3^{\text {rd }}$ generation extended for five months with population of 6591.5 \& 7146.7 nymphs/leaflet and 5113.1 \& 5561.9 adults/leaflet at $21.4^{\circ} \mathrm{C} \& 65.5 \%$ R.H. and $22.8^{\circ} \mathrm{C} \&$ $66.2 \%$ R.H., for the $1^{\text {st }}$ and $2^{\text {nd }}$ year, respectively.

The shortest generation occurred in late summer in the two years, with duration of 3 months at field conditions of $26.3^{\circ} \mathrm{C} \& 66.0 \%$ R.H. and $27.8^{\circ} \mathrm{C} \& 64.8 \%$ R.H., for the $1^{\text {st }}$ and $2^{\text {nd }}$ year, respectively. The longest generation occurred in autumn with duration of 5 months at $21.4^{\circ} \mathrm{C} \& 65.5 \%$ R.H. and $22.8^{\circ} \mathrm{C} \& 66.2 \%$ R.H., for the $1^{\text {st }}$ and $2^{\text {nd }}$ year, respectively, followed by intermediate generation occurred in early summer with duration of 4 months in the two years at $22.8^{\circ} \mathrm{C} \& 63.6 \%$ R.H. and $24.9^{\circ} \mathrm{C} \& 63.4 \%$ R.H. for the $1^{\text {st }}$ and $2^{\text {nd }}$ year, respectively.

On the other hand, the generation size varied in the two years, the autumn generation is the largest one $\left(12259.8 \& 12153.4\right.$ insects/leaflet) for the $1^{\text {st }}$ and $2^{\text {nd }}$ year, respectively, followed by late summer generation size (8184.2 \& 7430.4 insects/leaflet), for the $1^{\text {st }}$ and $2^{\text {nd }}$ year, respectively. Early summer generation size (6688.3 \& 7422.1 insects/leaflet), for the $1^{\text {st }}$ and $2^{\text {nd }}$ year, respectively.

Table 1. Number and durations of annual field generations of $F$. phoenicis on date palm at Baharia Oases, Giza Governorate in the $1^{\text {st }}$ year $(2012 / 2013)$.

\begin{tabular}{|c|c|c|c|c|c|c|c|c|c|c|c|}
\hline \multirow[b]{2}{*}{ Generation } & \multicolumn{3}{|c|}{ Generation duration } & \multirow{2}{*}{ 胥 } & \multicolumn{3}{|c|}{ Generation size } & \multicolumn{4}{|c|}{ Mean daily weather factors } \\
\hline & From & To & Peak & & Nymph & Adult & $\begin{array}{c}\text { Total } \\
\text { population }\end{array}$ & $\begin{array}{l}\text { Max. } \\
\text { Temp } \\
{ }^{\circ} \mathrm{C}\end{array}$ & $\begin{array}{l}\text { Min. } \\
\text { Temp. } \\
{ }^{\circ} \mathrm{C}\end{array}$ & $\begin{array}{c}\text { Mean } \\
\text { Temp. } \\
{ }^{\circ} \mathrm{C}\end{array}$ & $\begin{array}{c}\% \\
\text { RH }\end{array}$ \\
\hline $\begin{array}{l}1^{\text {st Generation }} \\
\text { (Early } \\
\text { summer) }\end{array}$ & $\begin{array}{c}\text { Mid } \\
\text { April }\end{array}$ & $\begin{array}{l}\text { Mid } \\
\text { Aug. }\end{array}$ & $\begin{array}{l}\text { Mid- } \\
\text { June }\end{array}$ & 4 & 4370.0 & 2318.3 & 6688.3 & 31.1 & 14.5 & 22.8 & 63.4 \\
\hline $\begin{array}{l}2^{\text {nd }} \text { Generation } \\
\text { (Late summer) }\end{array}$ & $\begin{array}{c}1^{\text {st }} \\
\text { Aug. }\end{array}$ & $\mathbf{1}^{\text {st Nov. }}$ & $\begin{array}{l}\text { Mid- } \\
\text { Sep. }\end{array}$ & 3 & 5231.1 & 2953.1 & 8184.2 & 33.4 & 19.2 & 26.3 & 66.0 \\
\hline $\begin{array}{l}3^{\text {rd Generation }} \\
\text { (Autumn } \\
\text { season) }\end{array}$ & $\begin{array}{l}\text { Mid- } \\
\text { Sep. }\end{array}$ & $\begin{array}{l}\text { Mid } \\
\text { Feb. }\end{array}$ & $\begin{array}{l}\text { Mid } \\
\text { Nov. }\end{array}$ & 5 & 7146.7 & 5113.1 & 12259.8 & 27.9 & 14.8 & 21.4 & 65.5 \\
\hline
\end{tabular}


Table 2. Number and durations of annual field generations of $F$. phoenicis on date palm at Baharia Oases, Giza Governorate in the $2^{\text {nd }}$ year (2013/2014).

\begin{tabular}{|c|c|c|c|c|c|c|c|c|c|c|c|}
\hline \multirow[b]{2}{*}{ Generation } & \multicolumn{3}{|c|}{ Generation duration } & \multirow{2}{*}{ 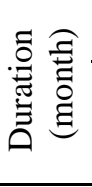 } & \multicolumn{3}{|c|}{ Generation size } & \multicolumn{4}{|c|}{ Mean daily weather factors } \\
\hline & From & To & Peak & & Nymph & Adult & $\begin{array}{c}\text { Total } \\
\text { population }\end{array}$ & $\begin{array}{l}\text { Max. } \\
\text { Temp. } \\
{ }^{\circ} \mathrm{C}\end{array}$ & $\begin{array}{l}\text { Min. } \\
\text { Temp. } \\
{ }^{\circ} \mathrm{C}\end{array}$ & $\begin{array}{l}\text { Mean } \\
\text { Temp. } \\
{ }^{\circ} \mathrm{C}\end{array}$ & $\begin{array}{c}\% \\
\mathrm{RH}\end{array}$ \\
\hline $\begin{array}{l}1^{\text {st }} \text { Generation } \\
\text { (Early summer) }\end{array}$ & $\begin{array}{c}1^{\text {st }} \\
\text { May }\end{array}$ & $\begin{array}{l}1^{\text {st }} \\
\text { Sep. }\end{array}$ & $\begin{array}{l}1^{\text {st }} \\
\text { Jul. }\end{array}$ & 4 & 4567.7 & 2854.4 & 7422.1 & 33.4 & 16.4 & 24.9 & 63.6 \\
\hline $\begin{array}{l}2^{\text {nd }} \text { Generation } \\
\text { (Late summer) }\end{array}$ & $\begin{array}{l}\text { Mid } \\
\text { Jul. }\end{array}$ & $\begin{array}{l}\text { Mid } \\
\text { Oct. }\end{array}$ & $\begin{array}{l}1^{\text {st }} \\
\text { Sep. }\end{array}$ & 3 & 4472.5 & 2957.9 & 7430.4 & 36.1 & 19.4 & 27.8 & 64.8 \\
\hline $\begin{array}{l}3^{\text {rd }} \text { Generation } \\
\text { (Autumn } \\
\text { season) }\end{array}$ & $\begin{array}{l}1^{\text {st }} \\
\text { Sep. }\end{array}$ & $\begin{array}{l}\text { Late } \\
\text { Jan. }\end{array}$ & $\begin{array}{c}1^{\text {st }} \\
\text { Nov. }\end{array}$ & 5 & 6591.5 & 5561.9 & 12153.4 & 29.4 & 16.1 & 22.8 & 66.2 \\
\hline
\end{tabular}

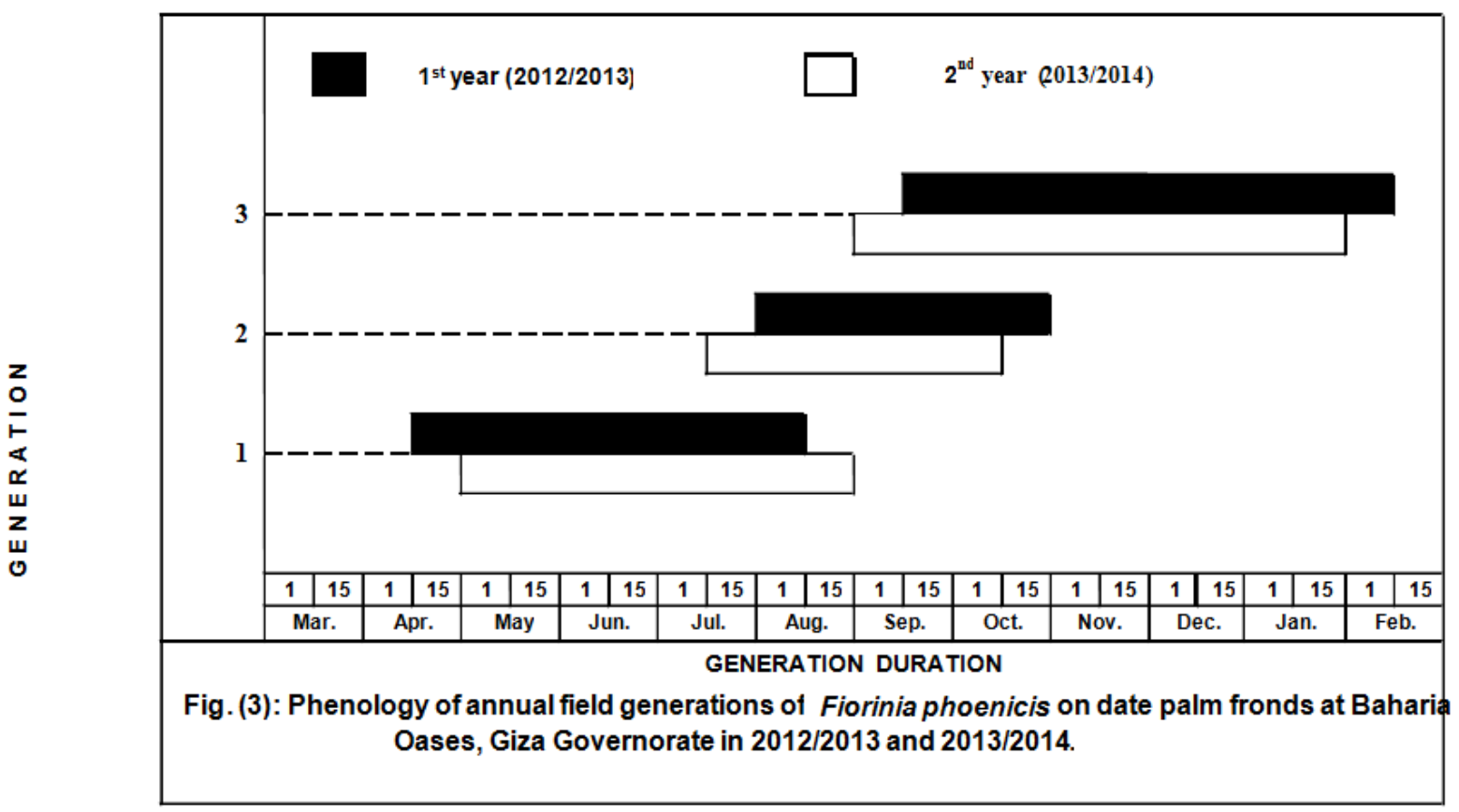

In Egypt, Elwan et al. (2011) pointed out that, Fiorinia phoenicis occurred on date palm fronds all the year round and has three overlapping generations a year on date palm at Giza governorate. The $1^{\text {st }}$ generation (early summer generation) peaked in early June and the $2^{\text {nd }}$ generation (late summer generation) peaked around August/September, whereas the $3^{\text {rd }}$ generation (autumn generation) peaked in October/November. The shortest generation was the late summer generation (2.5-3.0 months) at $27.9-28.6^{\circ} \mathrm{C}$ and $63.5-64.8 \%$ R.H., whereas the longest one was autumn generation (4.5 months) at $21.6-22.0^{\circ} \mathrm{C}$ and $65.9-66.3 \%$ R.H. The early summer generation had intermediate duration (4.0-4.5 months) at $20.9-21.2^{\circ} \mathrm{C}$ and $62.5-63.0 \%$ R.H in the two years, respectively. The population density varied in the three generations, the autumn generation was the largest one followed by late summer generation whereas the smallest one was the early summer generation.

Cardinal distribution of $F$. phoenicis population on date palm fronds.

The cardinal distribution of $F$. phoenicis population on the date palm fronds varied significantly in the four cardinal directions (Table, 3 \& Figs., 4, 5) in the two years, respectively. In the $1^{\text {st }}$ year, the southern direction received the highest portion of insect population (240.3 insects/leaflet), followed descendingly by eastern direction (225.1 insects/leaflet), Northern direction (218.3 insects/leaflet), and west direction (213 insects/leaflet), respectively without significant differences between each other.

In the $2^{\text {nd }}$ year, the cardinal distribution of insect population on the date palm fronds had the 
same manner. The south direction received the highest population (247.9 insects/leaflet), followed by west, east and north directions $(215.3,211.6$ and 211.3 insects/leaflet), respectively, without significant difference between means.

It could be observed that, the distribution of insect population on the date palm fronds in the cardinal directions was similar in the two years expect south direction. During the $1^{\text {st }}$ year, the south direction received the highest portion of insect population $(26.8 \%)$ followed by east $(25.1 \%)$, north $(24.9 \%)$ and west $(23.8 \%)$ directions, respectively. In the $2^{\text {nd }}$ year, the south direction received the highest portion of insect population $(28 \%)$ followed by west $(24.3 \%)$, east $(23.9 \%)$ and north $(23.8 \%)$ directions, respectively.

Table 3. Cardinal distribution of F. phoenicis population on date palm fronds at Baharia Oases, Giza Governorate in 2012/2013 and 2013/2014.

\begin{tabular}{lcccc}
\hline \multirow{2}{*}{ Direction } & \multicolumn{4}{c}{ Mean number of insect population /direction } \\
\cline { 2 - 5 } & $1^{\text {st }}$ year $(2012 / 2013)$ & $\%$ & $2^{\text {nd }}$ year $(2013 / 2014)$ & $\%$ \\
\hline North & $218.3(\mathrm{bc})$ & 24.3 & $211.3(\mathrm{~b})$ & $237.9(\mathrm{a})$ \\
South & $240.3(\mathrm{a})$ & 26.8 & $211.6(\mathrm{~b})$ & 28.0 \\
East & $225.1(\mathrm{~b})$ & 25.1 & $215.3(\mathrm{~b})$ & 23.9 \\
West & $213.0(\mathrm{c})$ & 23.8 & 886.1 & 24.3 \\
Total & 896.7 & 100.0 & $4.9 * *$ & 100.0 \\
F value & $14.0^{* *}$ & & 22.6 & \\
LSD at 5\% & 8.9 & & & \\
\hline
\end{tabular}

The obtained results indicated that, the south direction received the highest portion of insect population in the two years, respectively. So, it may be concluded that, $F$. phoenicis prefers to accumulate at the southern sides of the date palm trees, usually being relatively warmer than the other sides and become more preferred for infestation than the other sides which received almost similar populations.

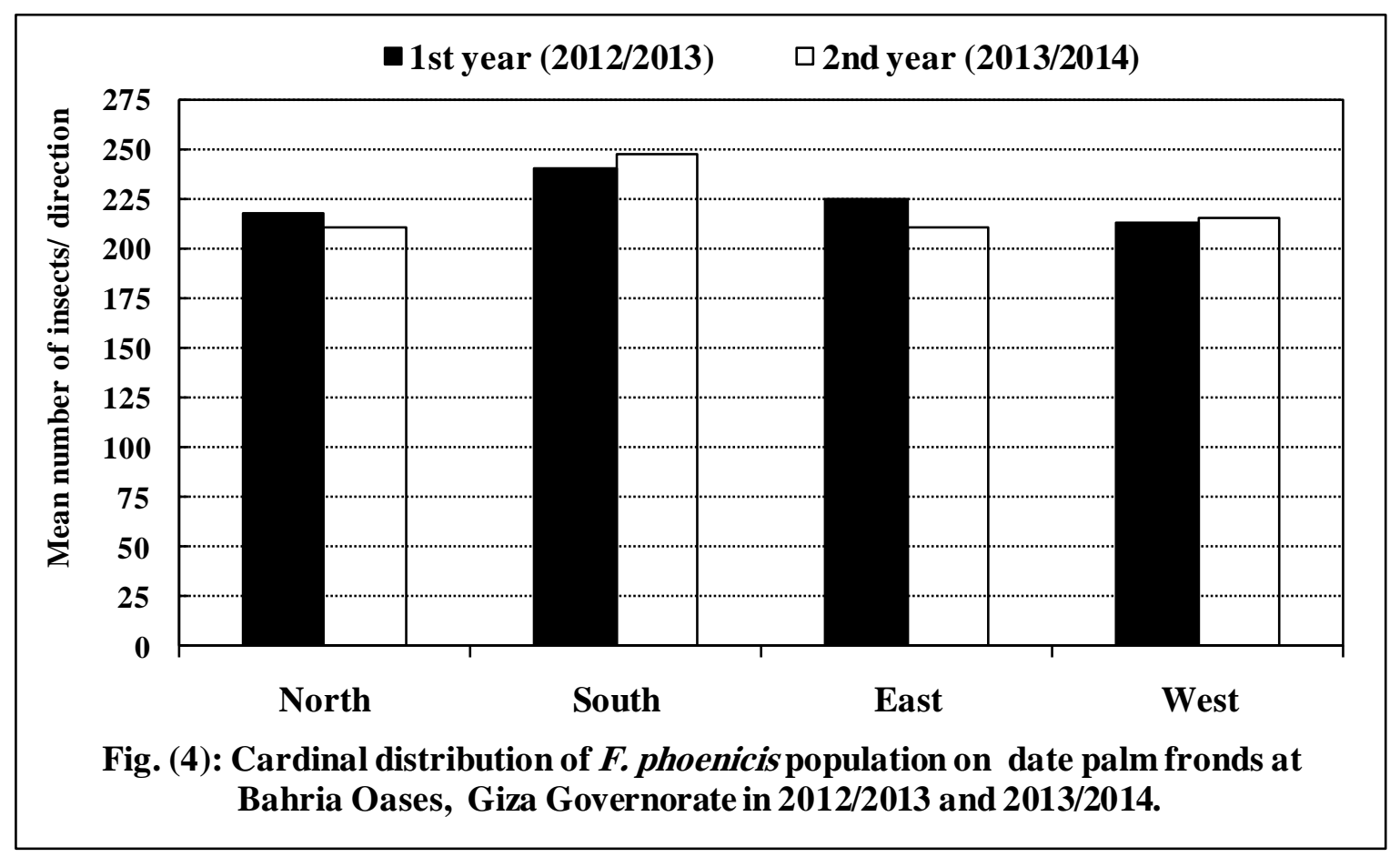




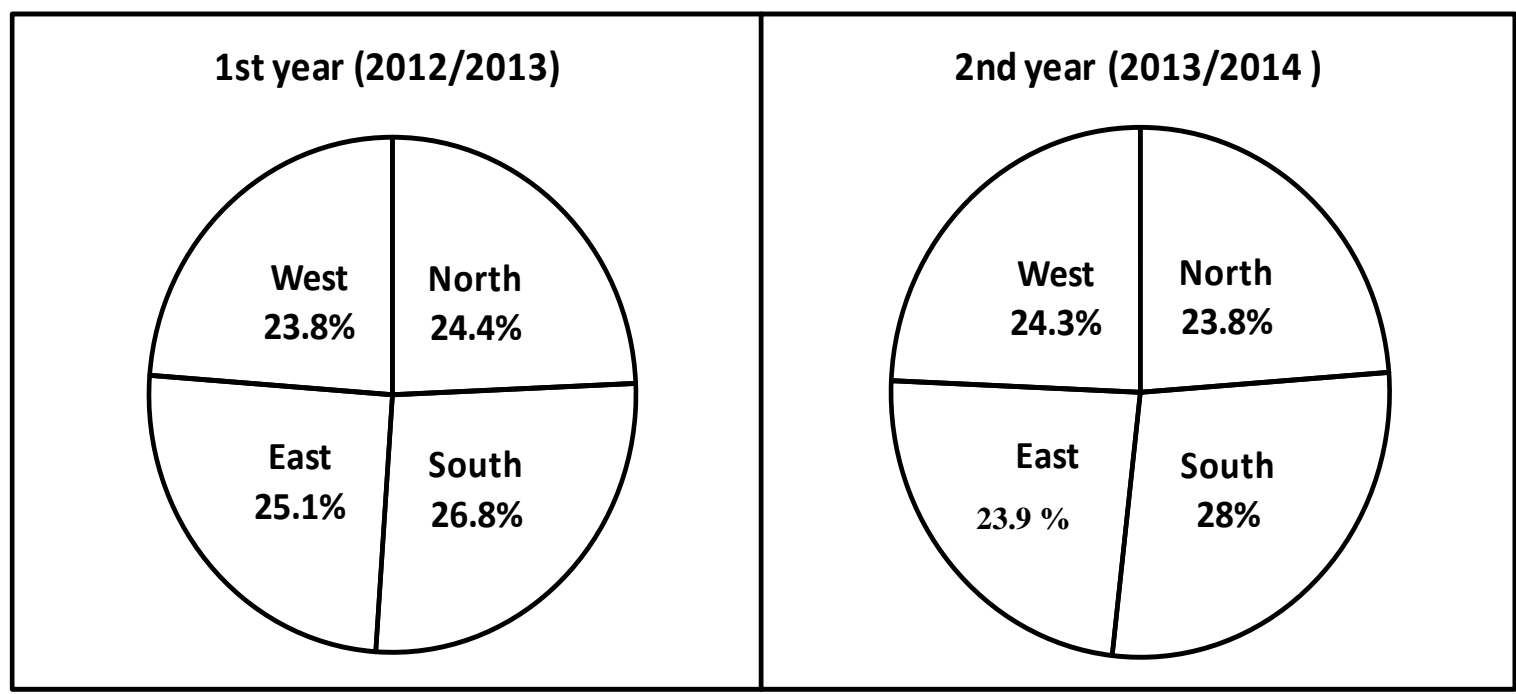

Fig. (5): Relative distribution of $F$. phoenicis population on the cardinal directionsof date palm fronds at Baharia Oases, Giza Governorate in 2012/2013 and 2013/2014.

Distribution of insect population on the different parts of the date palm leaflets

The distribution of $F$. phoenicis population on the different parts of the date palm leaflets (Table, 4 \& Figs., 6, 7) varied significantly in the two years. During the $1^{\text {st }}$ year, the middle stratum received the highest portion of insect population (358.6 insects/leaflet), followed by basal stratum (308.0 insects/leaflet), being in the $2^{\text {nd }}$ order, whereas the apical stratum received the lowest portion (230.6 insect/leaflet) of insect population and came in the last order.

In the $2^{\text {nd }}$ year, the distribution of $F$. phoenicis population had the same trend. The middle stratum received the highest portion of insect population (370 insects/leaflet), followed by basal stratum (284.6 insects/leaflet) being in the $2^{\text {nd }}$ order, whereas apical stratum received the lowest portion of insect population (199.2 insects/leaflet).

Table 4. Distribution of $F$. phoenicis population on the different strata of the date palm leaflets at Baharia Oases, Giza Governorate in 2012/2013 and 2013/2014.

Mean number of insect population / stratum

\begin{tabular}{|c|c|c|c|c|}
\hline Stratum & $\begin{array}{c}1^{\text {st }} \text { year } \\
(2012 / 2013)\end{array}$ & $\%$ & $\begin{array}{c}2^{\text {nd }} \text { year } \\
(2013 / 2014)\end{array}$ & $\%$ \\
\hline Apical stratum & $230.6(c)$ & $25.7 \%$ & $199.2(\mathrm{c})$ & $23.3 \%$ \\
\hline Middle stratum & 358.6 (a) & $40.0 \%$ & 370.0 (a) & $43.4 \%$ \\
\hline Basal stratum & 308.0 (b) & $34.3 \%$ & $284.6(b)$ & $33.3 \%$ \\
\hline Total population & 897.2 & 100 & 853.8 & 100 \\
\hline F value & $79.2 * *$ & & $78.3 * *$ & \\
\hline LSD at $5 \%$ & 20.6 & & 27.5 & \\
\hline
\end{tabular}




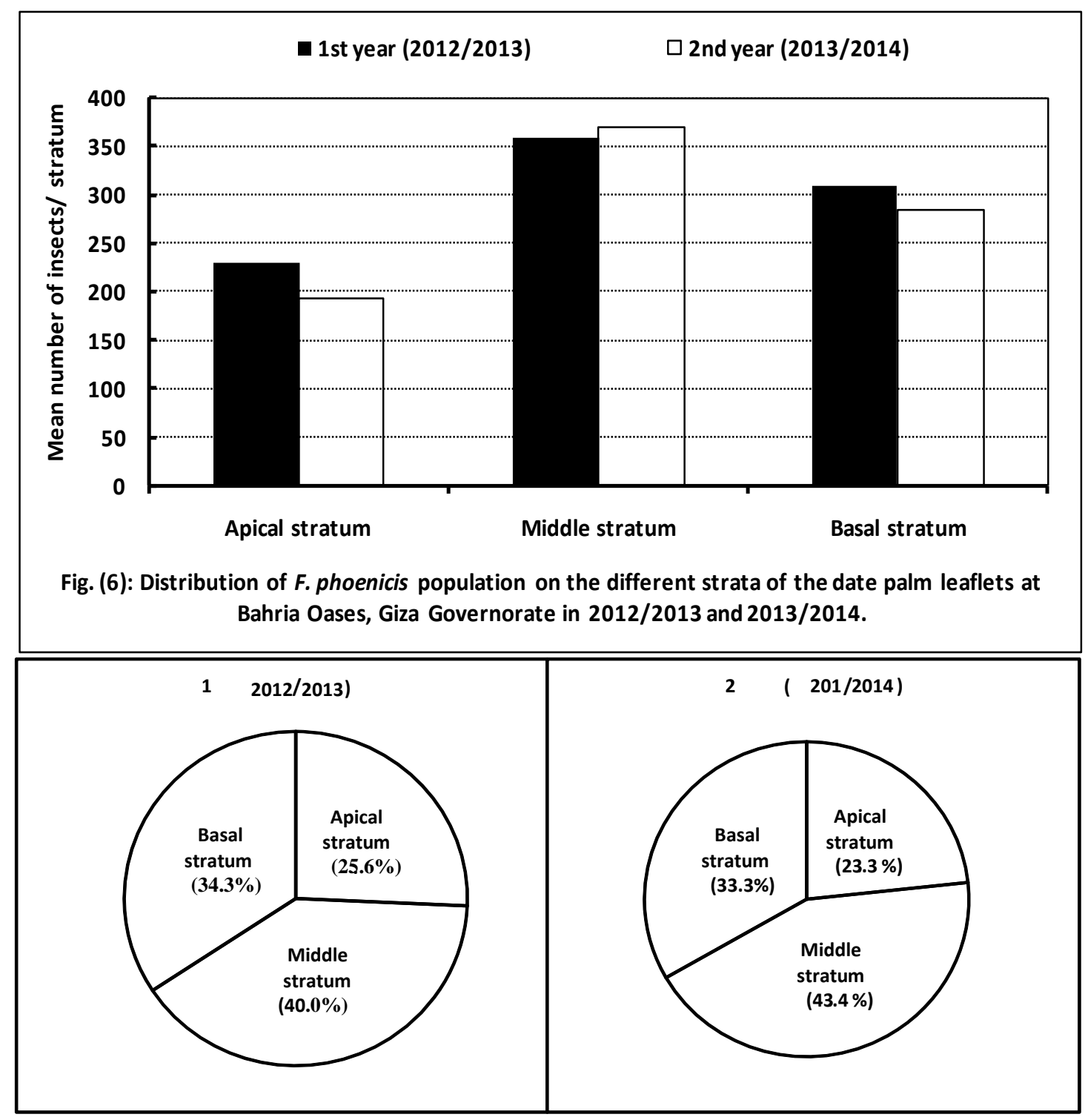

Fig. (7): Relative distribution of $F$. phoenicis population on different strata of the date palm leaflets at Baharia Oases, Giza Governorate in 2012/2013 and 2013/2014.

Effect of weather factors on the seasonal activity of $\boldsymbol{F}$. phoenicis

A- Nymphal population

1- Effect of daily mean minimum temperature

The obtained results (Table, 5) showed highly significantly positive response $(r=0.673 \& 0.732)$ for daily mean minimum temperature on the nymphal activity in the two years. The effect of daily mean minimum temperature was positive (P. reg. values = $99.9 \& 28.5)$ on the nymphal activity in the two years being highly significant in the $1^{\text {st }}$ year and non significant in the $2^{\text {nd }}$ one.

\section{2- Effect of daily mean maximum temperature}

Daily mean maximum temperature showed highly significantly positive relation ( $\mathrm{r}$ values $=0.534$ $\& 0.581$ ) on the nymphal activity in the two years (Table 5).The effect of this factor was nonsignificant (P. reg. values $=-49.2 \& 4.5)$ in the two years being negative in the $1^{\text {st }}$ year and positive in the $2^{\text {nd }}$ one (Table, 5).

3- Effect of daily mean relative humidity (\%R.H.)

Relative humidity (\% R.H.) had positive effect on nymphal activity ( $\mathrm{r}$ values $=0.490 \& 696$ ) being significant in the $1^{\text {st }}$ year and highly significant in the $2^{\text {nd }}$ one. The effect of $\%$ R.H. on the nymphal activity was positively non-significant in the $1^{\text {st }}$ year and highly significant in the $2^{\text {nd }}$ year $(P$. reg. values $=$ $18.7 \& 50.2$ ), (Table,5).

\section{4-Combined effect of the tested weather factors on} the nymphal activity

The obtained results (Table, 5) showed that, the combined effect of the tested weather factors on the nymphal activity was highly significant ( $\mathrm{F}$ values = $10.7 \& 17.6)$ in both years of study, respectively. The changes in the half monthly counts of the nymphal population may be attributed to the effect of the 
tested weather factors that ranged from $61.6-72.5 \%$. The forementioned results emphasized that, the effects of these factors varied from year to year and daily mean minimum temperature and \%R.H. have a detectable effect on the nymphalactivity of $F$. phoenicis

Table 5. Effect of tested weather factors on $F$. phoenicis population on date palm at Baharia Oases, Giza Governorate in2012/2013 and 2013/2014.

\begin{tabular}{|c|c|c|c|c|c|c|c|c|c|c|c|}
\hline \multirow{3}{*}{ 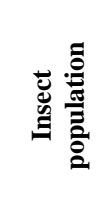 } & \multirow{3}{*}{$\begin{array}{l}\text { Weather } \\
\text { Factor }\end{array}$} & \multicolumn{5}{|c|}{ 1st year $(2012 / 2013)$} & \multicolumn{5}{|c|}{ 2nd year $(2013 / 2014)$} \\
\hline & & \multirow{2}{*}{$\begin{array}{c}\text { Simple } \\
\text { correlation } \\
\mathbf{r}\end{array}$} & \multicolumn{2}{|c|}{$\begin{array}{c}\text { Partial regression } \\
\text { values }\end{array}$} & \multicolumn{2}{|c|}{ ANOVA T } & \multirow{2}{*}{$\begin{array}{c}\begin{array}{c}\text { Simple } \\
\text { correlation }\end{array} \\
\mathbf{r}\end{array}$} & \multicolumn{2}{|c|}{$\begin{array}{c}\text { Partial regression } \\
\text { values }\end{array}$} & \multicolumn{2}{|c|}{ ANOVA T } \\
\hline & & & P. reg. \pm s.e & $\begin{array}{c}\mathbf{t} \\
\text { value }\end{array}$ & $\begin{array}{c}\mathbf{F} \\
\text { value }\end{array}$ & $\begin{array}{c}\text { E.V. } \\
\%\end{array}$ & & $\begin{array}{l}\text { P. reg. } \pm \\
\text { s.e }\end{array}$ & $\begin{array}{c}\text { t } \\
\text { value }\end{array}$ & $\begin{array}{c}\mathbf{F} \\
\text { value }\end{array}$ & $\begin{array}{c}\text { E.V. } \\
\%\end{array}$ \\
\hline \multirow{3}{*}{ 言 } & Min.Temp. ${ }^{\circ} \mathbf{C}$ & $0.673 * *$ & $99.9 \pm 32.7$ & $3.10 * *$ & \multirow{3}{*}{$10.7 * *$} & \multirow{3}{*}{61.6} & $0.732 * *$ & $28.5 \pm 9.1$ & 0.98 & \multirow{3}{*}{$17.6^{* * *}$} & \multirow{3}{*}{72.5} \\
\hline & Max. Temp. ${ }^{\circ} \mathrm{C}$ & $0.534 * *$ & $-49.2 \pm 25.5$ & -1.9 & & & $0.581 * *$ & $4.5 \pm 1.9$ & 0.23 & & \\
\hline & \% R.H. & $0.490 *$ & $18.7 \pm 11.7$ & 1.6 & & & $0.696 * *$ & $50.2 \pm 16.9$ & $3.0 * *$ & & \\
\hline \multirow{3}{*}{ 㐏 } & Min.Temp. ${ }^{\circ} \mathrm{C}$ & $0.505^{*}$ & $91.3 \pm 21.6$ & $4.2 * *$ & \multirow{3}{*}{$9.8 * *$} & \multirow{3}{*}{59.4} & $0.553 * *$ & $44.4 \pm 22.9$ & 1.9 & \multirow{3}{*}{$13.3^{* *}$} & \multirow{3}{*}{66.7} \\
\hline & Max. Temp. ${ }^{\circ} \mathrm{C}$ & 0.304 & $-59.7 \pm 16.8$ & $-3.6 * *$ & & & 0.324 & $-21.3 \pm 15.4$ & -1.4 & & \\
\hline & \% R.H. & $0.426 *$ & $7.8 \pm 5.7$ & 1.01 & & & $0.748 * *$ & $32.8 \pm 13.3$ & $2.5^{* * *}$ & & \\
\hline \multirow{3}{*}{ 苞泀 } & Min.Temp. ${ }^{\circ} \mathbf{C}$ & $0.624 * *$ & $191.2 \pm 51.8$ & $3.7 * *$ & \multirow{3}{*}{$10.9 * *$} & \multirow{3}{*}{62.1} & $0.684 * *$ & $72.9 \pm 35.3$ & 1.54 & \multirow{3}{*}{$18.4^{* * *}$} & \multirow{3}{*}{73.4} \\
\hline & $=$ Max. Temp. $^{\circ} \mathrm{C}$ & $0.457 *$ & $-108.9 \pm 40.4$ & $-2.7 * *$ & & & $0.493^{*}$ & $-16.8 \pm 9.2$ & -0.5 & & \\
\hline & \% R.H. & $0.478 *$ & $26.5 \pm 18.6$ & 1.43 & & & $0.747 * *$ & $83.0 \pm 27.4$ & $3.03 * *$ & & \\
\hline
\end{tabular}

\section{B -Adult population}

\section{1- Effect of daily mean minimum temperature}

Daily mean minimum temperature showed positive relation with adult's activity in the two years (Table, 5), being significant in the $1^{\text {st }}$ year ( $\mathrm{r}$ value $=0.505)$ and highly significant $(\mathrm{r}$ value $=0.553)$ in the $2^{\text {nd }}$ one. The effect of this factor was positive (P. reg. values $=91.3 \& 44.4$ ) on the adult activity in the two years of study, being highly significant in the $1^{\text {st }}$ year and non-significant in the $2^{\text {nd }}$ one.

\section{2- Effect of daily mean maximum temperature}

Daily mean maximum temperature showed positive non-significant response on $F$. phoenicis activity ( $\mathrm{r}$ values $=0.304 \& 0.324$ ) in the two years, respectively. The effect was negatively (P. reg. = $59.7 \&-21.3$ ) in the two years, being highly significant in the $1^{\text {st }}$ year and nonsignificant in the $2^{\text {nd }}$ one (Table, 5).

3- Effect of daily mean relative humidity (\%R.H.)

Daily mean relative humidity (\%R.H.) had positive effect on the adult population in the two years, being significant in the $1^{\text {st }}$ year and highly significant in the $2^{\text {nd }}$ one. The effect of $\%$ R.H. on the adult activity was positively non-significant ( $\mathrm{P}$. reg. values=7.5 \& 32.8) in the $1^{\text {st }}$ year and highly significant in the $2^{\text {nd }}$ year (Table, 5).

\section{4-Combined effect of the tested weather factors on the adult population}

The combined effect of the tested weather factors on the adult population of $F$. phoenicis was highly significant $(\mathrm{F}$ values $=9.8 \& 13.3)$ in both years, (Table, 5). The changes in the half monthly counts of the adult population indicated that the effect of tested weather factors ranged 59.4-66.7\%.

\section{C - Total population \\ 1- Effect of daily mean minimum temperature}

Daily mean minimum temperature significantly correlated with the insect population in the two years $(r$ values $=0.624 \& 0.684)$. The effect of this factor on the insect activity was positive in the two years (P. reg. values $=191.2 \& 72.9$ insects $/$ leaf $)$, being highly significant in the $1^{\text {st }}$ year and nonsignificant in the $2^{\text {nd }}$ one (Table, 5 ).

\section{2- Effect of daily mean maximum temperature}

Daily mean maximum temperature showed significantly positive effect on the $F$. phoenicis population in the two years, whereas, its effect was negative in the two years (P. reg. values $=-108.9 \&$ 16.8 ), being highly significant in the $1^{\text {st }}$ year and nonsignificant in the $2^{\text {nd }}$ one (Table, 5)

\section{3- Effect of daily mean relative humidity (\%R.H.)}

Daily mean relative humidity has significant positive effect on the insect population $(r=0.478)$ in the $1^{\text {st }}$ year and highly significant $(r=0.747)$ in the $2^{\text {nd }}$ one, while the effect of $\%$ R.H. on activity was positive in the two years ( $P$. reg. values $=26.5 \&$ 83.0 ), being nonsignificant in the $1^{\text {st }}$ year and highly significant in the $2^{\text {nd }}$ one (Table, 5).

\section{4- Combined effect of the tested weather factors on the insect population}

The combined effect of the tested weather factors on the $F$. phoenicis activity was highly significant $(F$ values $=10.9 \& 18.4)$ in two the years of study (Table, 5). The changes in the half monthly 
counts of the insect population may be referred to the effect of the tested weather factors ranged 62.1 and $73.4 \%$, respectively.

In Egypt, Elwan et al. (2011) stated that, the annual field generations of $F$. phoenicis on date palm at Giza Governorate was greatly affected by the daily mean temperature and \%R.H. The changes in the half monthly counts of the nymph and adult populations could be referred to combined effect of these weather factors ranged $66.1-69 \%$ \& $48.1-49.2 \%$ for the $1^{\text {st }}$ generation (early summer generation); 65.4-74.0\% $\& 63.8-78.4 \%$ in the $2^{\text {nd }}$ generation (late summer generation)and $60.9-77.4 \% \quad \& \quad 48.6-63.5 \%$ in the $3^{\text {rd }}$ generation (autumn generation) in the two years, respectively. While in similar studies, Radwan (2012) showed that, the durations of seasonal activity of $F$. phoenicis nymphs and adults were significantly affected with daily mean max. and min. temperatures as well as \%R.H. The combined effect of these factors on the nymphal activity ranged $58.2-74.8 \%$ in the $1^{\text {st }}$ period of activity and 66.9-74.8 in the $2^{\text {nd }}$ one in the two years whereas the combined effect of these factors on the adult activity ranged $53.9-76.3 \%$ in the $1^{\text {st }}$ period and $84.9-87.9 \%$ in the $2^{\text {nd }}$ one for the two years, respectively.

\section{References}

Balachowsky, A. S. (1967):Une espèce nouvelle de Fiorinia (Coccoidea - Diaspidini) vivant surpalmeir-dattierdans les Oasis du sud de 1'lran.Ann. Soc. Ent. France, 3: 771-775.

Elwan, E. A. (2000): Survey of the insect and mite pests associated with date palm trees in AlDakhliya Region, Sultanate of Oman. Egypt. J. Agric. Res., 78(2):653-664.

Elwan, E. A.; I. E. Maha and A. M. $\operatorname{Serag(2011):Seasonal~activity~of~fiorinia~date~}$ scale, Fiorinia phoenicis Balachowsky (Hemiptera - Diaspididae) on date palm at Giza Governorate, Egypt. Egypt. J. Agric. Res.; 89(2):549 - 565.

Fisher, A. R. (1950): Statistical methods for research worker. Oliver and Boyd, Edinburgh and London.

Ghabbour, M.W. and Z.K. Mohammad (2010): Fiorinia phoenicis (Hemiptera: Coccoidea: Diaspididae) new pest of palm trees in Egypt. J. Egypt. Ger. Soc. Zool., 58(E): 15-20.
Hussain, A. A. (1974): Date palms and dates with their pests in Iraq. Univ. Baghdad, Ministry of Higher Educ. Sci. Res. Baghdad, 244 pp.

Matile, F. D. (1984): Insects of Saudi Arabia Homoptera: Suborder Coccoidea. Fauna of Saudi Arabia, 6 : 219-228.

Mohammed, Z.K. and M.W. Ghabbour (2008): Updating list of super family Coccoidea (Hemiptera) as known to exist in Egypt. 18th International Conference of the Egyptian German society of Zoology, 1-5 March 2008, Faculty of Girls, Ain Shams University.

Radwan, S. G. (2012): Seasonal fluctuation of fiorinia date scale, Fiorinia phoenicis Balachowsky(Hemiptera-Diaspididae) populations on date palm trees at Qalubyia Governorate, Egypt. Journal of Basic \& Applied Zoology, 65: 47-54.

Seljak, G. and F. D. Matile(2012):First record of FioriniaphoenicisBalachowsky, 1967, in Europe (Hemiptera, Diaspididae). Bulletin de la Société Entomologique de France, 117(4): 453-455.

Takagi, S. and M. Moghaddam (2005): New or noteworthy armored scale insects occurring in Iran (Homoptera: Coccoidea: Diaspididae). Ins. Matsum. n. s. 61:43-74. 


\title{
ديناميكية تعـداد حشـــرة فيورينيا النخيل القشـرية Fiorinia phoenicis على نخـيل البلح فى الواحات البحرية ،

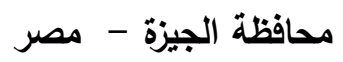

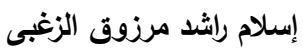 \\ كلية الزراعة والموارد الطبيعية -جامعة أسوان - أسوان - مصرئ
}

حشرة فيورينيا النخيل القشرية Fiorinia phoenicis من الآفات الحشرية الهامة النى تصيب نخيل البلح فى مصر حيث تسبب الاصابة

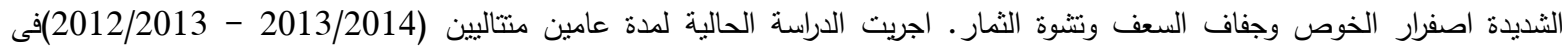

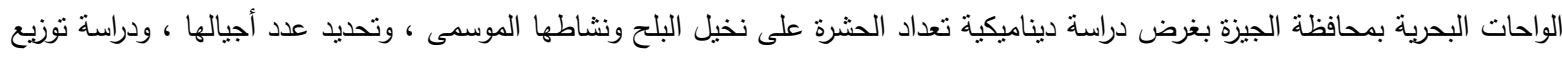

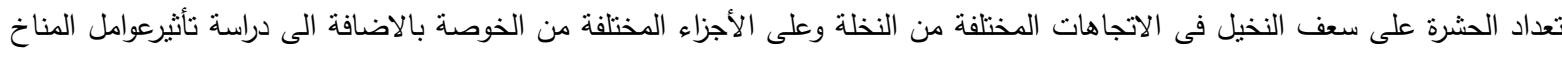

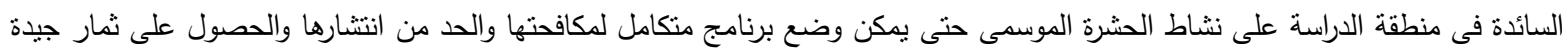
خالية من الإصابة الحشرية.

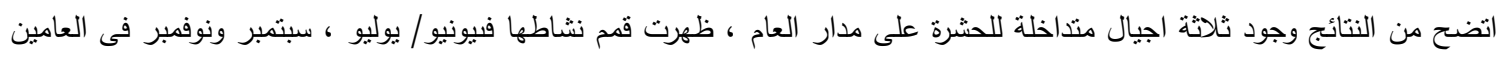

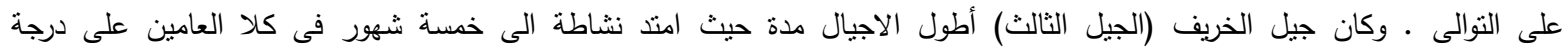

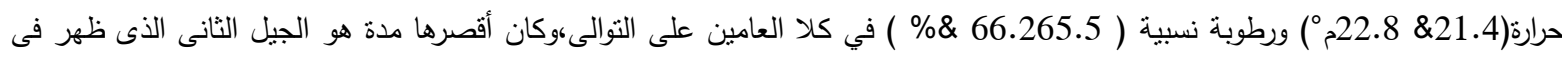

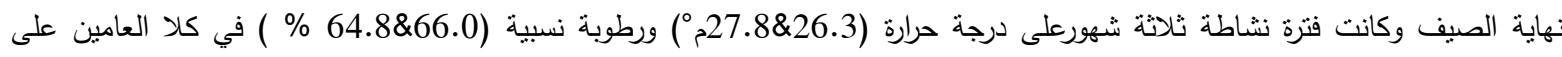

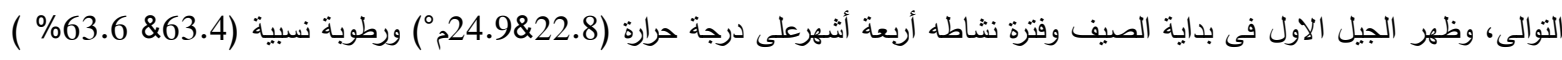

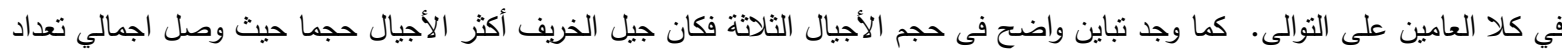

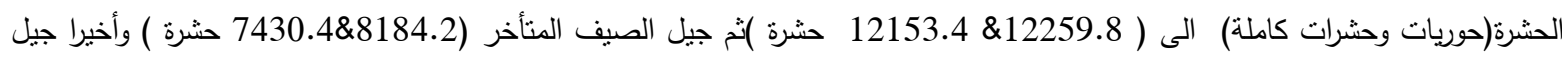
الصيف المبكر ( 6688.3 \& 7422.1 حشرة ) في كلا العامين على النوالى.

وتيين من الدراسة تواجد أطوار الحشرة على سعف النخيل على مدار العام وخاصة الأجزاء السفلية للسعف (السعف القديم) ويتوزع تعدادها

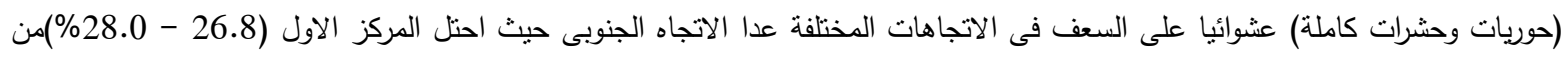

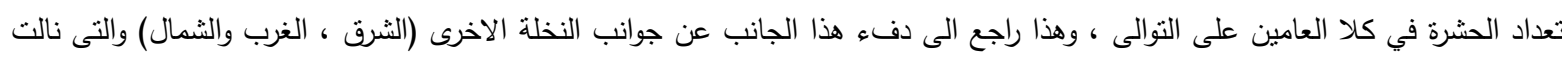

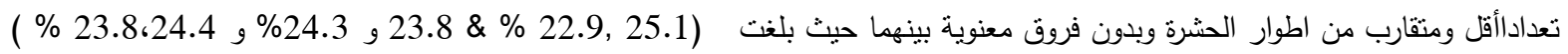
للاتجاه الثرقى والغربى والثمالى في كلا العامين على التوالى.

كما وجد تباين واضح فى درجة انتشار الحشرة على الخوص حيثوجدت اعداد كثيرة من اطوار الحشرة على التلث الوسطى من الخوصة

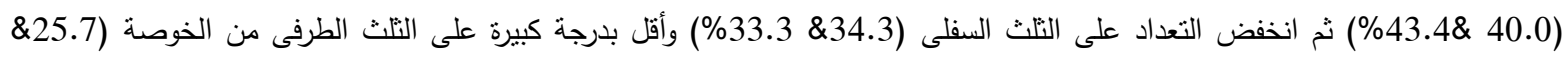
23.3 23.3) فى كلا العامين على التوالى.

كما نتأثنثاط الحشرة بالظروف الجوية السائدة (درجة الحرارة العظمى والدنيا والرطوبة النسبية) فى منطقة الدراسة فى كلا العامين ،وكان

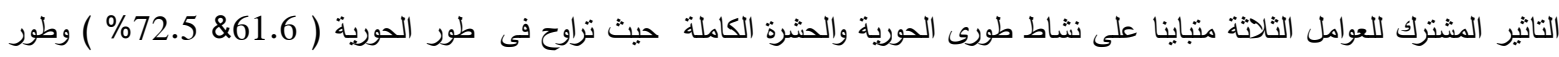

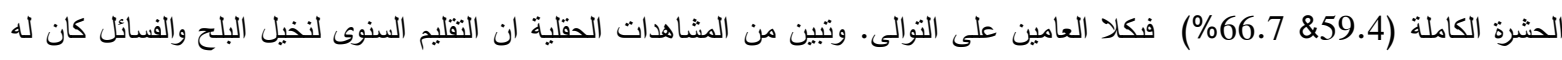

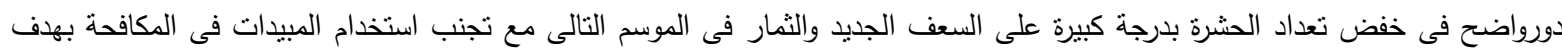

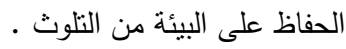

